Banadyga A.I., Banadyha N.V., Banadyga S.V. Early diagnosis and prevention of complications of acute pancreatitis. Journal of Education, Health and Sport. 2020;10(2):74-78. eISSN 2391-8306. DOI http://dx.doi.org/10.12775/JEHS.2020.10.02.010

https://apcz.umk.pl/czasopisma/index.php/JEHS/article/view/JEHS.2020.10.02.010

https://zenodo.org/record/3661464

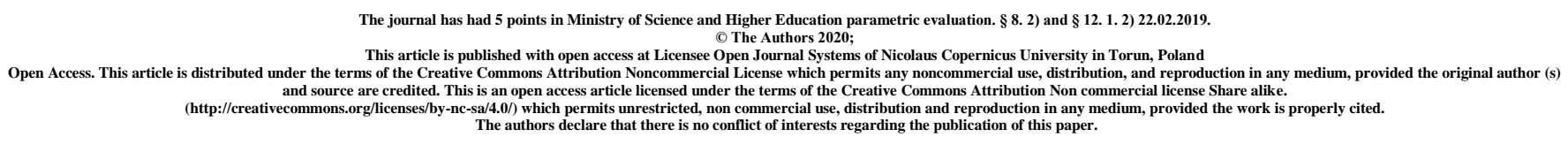

Received: 15.01.2020. Revised: 25.01.2020. Accepted: 10.02.2020.

\title{
Early diagnosis and prevention of complications of acute pancreatitis
}

\author{
A.I. Banadyga, N.V. Banadyha, S.V. Banadyga
}

I.Horbachevsky Ternopil National Medical University, Faculty of Postgraduate Education, Department of Surgery, Ternopil, Ukraine

\begin{abstract}
In order to make correct diagnosis of acute pancreatitis (AP) and prevention of complications, especially infected pancreatic necrosis (IPN), there were made a wide range of examinations of people with abdominal pain and appropriate anamnesis. Clinical, laboratory and instrumental examination methods were carried out in dynamics during the first 5-7 days of illness. Attention was paid to some laboratory methods (levels of procalcitonin (PCT), amylase, diastasis, ALT, AST) due to results of correlation analysis in our previous researches.
\end{abstract}

Key words: acute pancreatitis, infected pancreatic necrosis, procalcitonin,

Topicality. Pancreatitis is an inflammation of the pancreas. Acute pancreatitis is the number one gastrointestinal diagnosis prompting inpatient admission and ranks 21 st on the list of all diagnoses requiring hospitalization. The incidence of acute pancreatitis ranges from 13 to 45/100,000 with equal affinity for each gender (though with differing etiologies) [4].

Recently, the prevalence of AP has been periodically occupied by the second - third place among the urgent diseases of the abdominal organs [5]. Acute pancreatitis represents a disorder characterized by acute necroinflammatory changes of the pancreas and is histologically characterized by acinar cell destruction [1]. 
This disorder is associated with early activation of the digestive enzymes that are released into the small intestine during the digestive process than activating at the appropriate time to digest food, these enzymes attack the pancreatic tissue instead causing damage [2]

In $15 \%$ of patients there is an IPN, which is a surgical problem [ 5]. IPN is severe high mortality surgical disease (approaching 100\% in the absence of treatment)[9]. IPN is considered to be the cardinal feature of the late phase of AP [13]. However, several bouts of acute inflammation of the pancreas can result in a chronic pancreatitis diagnoses as well [4];

Acute pancreatitis sometimes causes problems to the patient and to the doctor because of unpredictable course that require timely and correct solution. Moreover, the role of early diagnosis based on specific complex of laboratory and instrumental methods of examination are significant. Determinants of disease severity in acute pancreatitis continue to be the subject of debate[12]. There is no unique doctrine of conservative and surgical treatment of IPN both in Ukraine and abroad. Literature discussionsare based on forecasting, timing of surgery, techniques of operating procedures[11]. The problem of non-invasive diagnosis of IPN is meaningful despite the fact that instrumental visualisation of the pancreas has reached a very high level $[9,10]$. One of possible ways to the problem of treatment of this disease is timely determination of the nature and extent of the destruction of the pancreas and retroperitoneal fat and making prognosis of the IPN. [7,11]. The diagnostic value in determining the level of procalcitonin in blood - biochemical marker of early diagnosis of sepsis in surgical pancreatology has not been studied enough, so the scientific research in this area is more than appropriate.

Objective: to make early diagnosis and prevent complications of AP.

\section{Materials and methods.}

All patients who were examined in this research had been treated at Ternopil University Hospital and Ternopil Municipal Hospital in a period from 2014 year to 2019 in amount of 230. They were divided into two groups due to the severity of AP and according to the International consultation (2012), which is the addition of Atlanta (1992): group I (light and medium AP), group II (severe and critical AP). Statistical analyzes was made in Statistica Soft 13.0

\section{Research results.}

Among examined with a light AP were - 82 (35,65\%), medium - 86 (37,39\%), severe - $44(19,13 \%)$, critical $-18(7,83 \%)$ patients. Medium age of patients was 44,5 $\pm 1,49$ in the first study group and 47,4 \pm 1,51 - in the second group

The I study group $(\mathrm{n}=168)$ included patients with medium AP (presence of sterile (pery) pancreatic necrosis and/or intermittent organ failure) while in the II study group $(n=62)$. were patients with severe AP (presence or infected (pery)pancreatic necrosis, or sustained organ failure) and critical AP (availability of infected (peri) pancreatic necrosis and sustained organ failure).

We analyzed 36 laboratory parameters on the 1st, 2nd, 3rd, 4th, 7th day of the disease. in order to detect the diagnostic and prognostic value of it. In the statistical analysis of the received material using the Student's test was evaluated the probability of the differences. Of all the 36 analyzed biochemical laboratory parameters allocated 9 (amylase, diastasis, ALT, AST, bilirubin, protein, glucose, hemoglobin, leukocytes), with a probable difference $(\mathrm{P}<0.05)$. Average levels of it are presented in Table 1. 


\begin{tabular}{|c|c|c|c|c|c|c|c|c|c|}
\hline $\begin{array}{l}\text { Research } \\
\text { Group }\end{array}$ & $\begin{array}{l}\text { Diasta- } \\
\text { sis, U/L }\end{array}$ & $\begin{array}{l}\text { Amy- } \\
\text { lase, } \\
\text { U/L }\end{array}$ & $\begin{array}{l}\text { Biliru- } \\
\text { bin, } \\
\mu \mathrm{m} / 1\end{array}$ & $\begin{array}{l}\text { Leuko- } \\
\text { cytes, } \\
\text { x } 10^{9}\end{array}$ & $\begin{array}{l}\text { Glucose } \\
\mathrm{mmol} / \mathrm{l}\end{array}$ & $\begin{array}{l}\text { ALT, } \\
\text { U/L }\end{array}$ & $\begin{array}{l}\text { AST, } \\
\text { U/L }\end{array}$ & $\begin{array}{l}\text { Hemoglobi } \\
\mathrm{n}, \mathrm{g} / \mathrm{l}\end{array}$ & $\begin{array}{l}\text { Total } \\
\text { protein, } \\
\mathrm{g} / \mathrm{l}\end{array}$ \\
\hline Group I & $\begin{array}{l}894,37 \\
\pm \\
126,12\end{array}$ & $\begin{array}{l}140,23 \\
\pm \\
12,15\end{array}$ & $\begin{array}{l}14,12 \\
\pm 0,8\end{array}$ & $\begin{array}{l}7,45 \pm 0, \\
14\end{array}$ & $7,1 \pm 0,2$ & $\begin{array}{l}33,8 \pm \\
1,14\end{array}$ & $\begin{array}{l}30,26 \pm \\
1,43\end{array}$ & $121,15 \pm 1,3$ & $\begin{array}{l}57,14 \pm \\
0,23\end{array}$ \\
\hline Group II & $\begin{array}{l}1537,1 \\
\pm 231,1 \\
4 * *\end{array}$ & $\begin{array}{l}269,16 \\
\pm \\
34,7 * *\end{array}$ & $\begin{array}{l}20,07 \\
\pm \\
1,46\end{array}$ & $\begin{array}{l}12,14 \pm \\
0,3^{*}\end{array}$ & $\begin{array}{l}7,8 \pm \\
0,12\end{array}$ & $\begin{array}{l}78,13 \\
\pm \\
10,45 \\
* *\end{array}$ & $\begin{array}{l}71,26 \pm \\
10,15^{*} \\
*\end{array}$ & $121,2 \pm 2,1$ & $\begin{array}{l}48,12 \pm \\
1,56^{*}\end{array}$ \\
\hline
\end{tabular}

Note: $* \mathrm{p}<0,05$ - reliability data between the first and second groups; $* * \mathrm{P}<0,01-$ reliability data between the first and second groups.

Table 1. Average levels of some laboratory parameters in I and II groups.

Levels of some laboratory parameters on different days had particlarities in studing groups. The biggest differences were detected in levels of diastasis. Average levels of diastasis were high in both groups on the first day of disease, but were higher in II group (Fig.1.). Rapid falling of it levels to three days was also in II group when in I group levels slowly fell down.

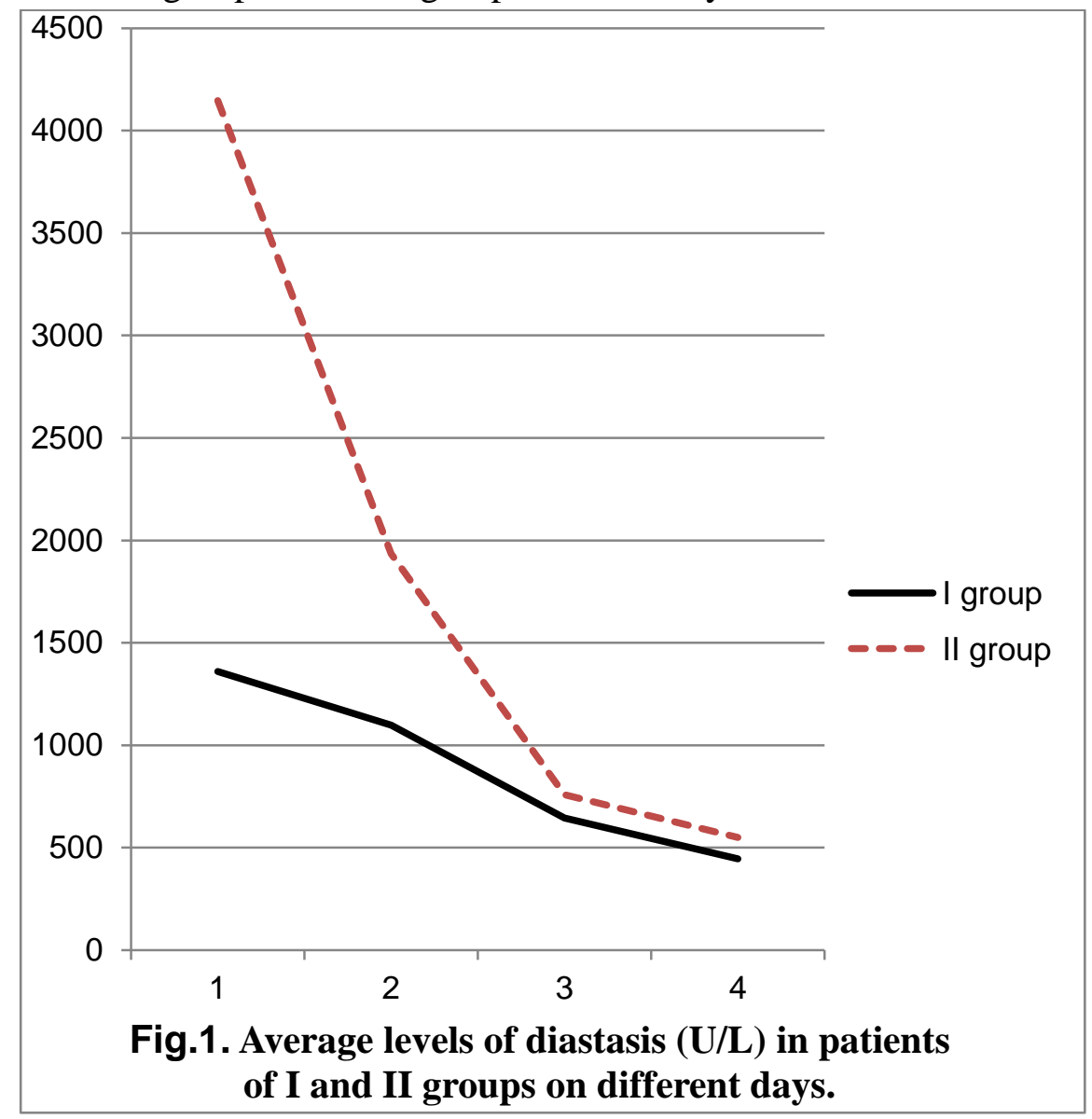


In the second group of patients at the time of admission was observed a significant leukocytosis in the blood and anemia combined with hypoproteinemia $(\mathrm{p}<0,05)$. In patients with severe and critical AP was diagnosed a high level of cytolysis (the contents of AST, ALT) and violation of exocrine function of pancreas, which reflects high amylase in blood.

In both groups of observation was tendency to hyperglycemia, which is alarming due to violation of the endocrine function of pancreas as a result of inflammatory-destructive process. Average rates of blood glucose were higher than normal in both groups during the first six days of observation, which means symptoms of pancreatic necrosis.

In order to make diagnosis of IPN and prevent complications we determined PCT level in blood - a marker of sepsis (Fig.2.)

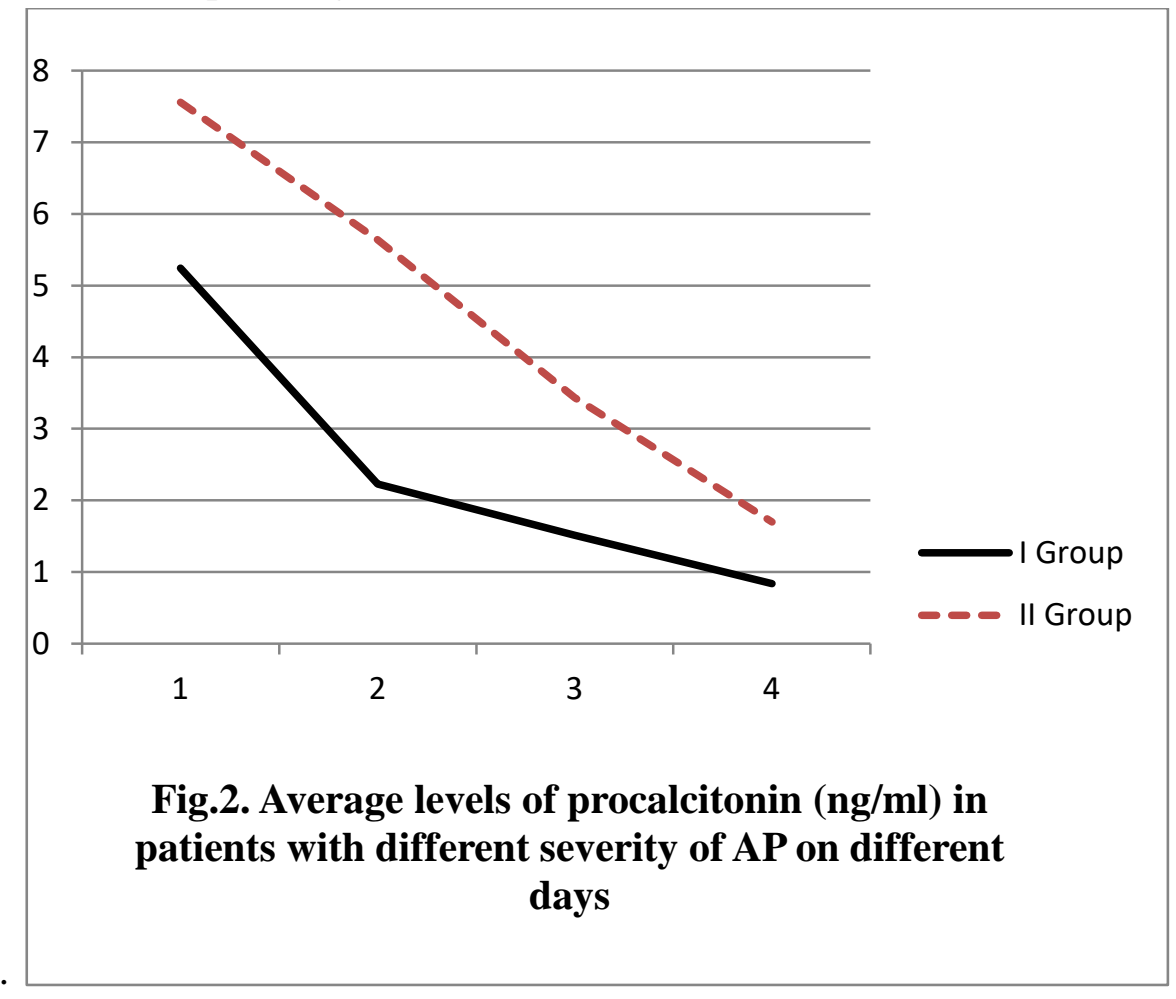

It was found that in 14 patients $(22,58 \%)$ of II group (severe and critical AP) the levels of marker were increased (> 2,0 $\mathrm{ng} / \mathrm{ml}$ ). These patients were operated in first three days being in hospital and septic inflammation was seen in all cases in operating room . IPN was evidenced in such way. Complications was only in 1 patient $(7,14 \%)$ In I group 12 patients had high levels of PCT, but surgical treatment was postponed in order to extra examination. Complications in this group was in 10 patients $(83,33 \%)$ despite the fact that patients had light or medium AP.

Ultrasonography at admission to hospital was informative in 93 patients of I group $(55,35 \%)$. In II group changes in the pancreas - characteristics of AP were found in 47 patients $(75,80 \%)$. CT was performed in 34 patients with severe and critical AP and diagnostic value it had in 21 patients $(61,76 \%)$. The next step to analyse all data was building correlation analysis of all these criteria. . Correlation matrix of connections for each patient group consisted of 197 correlation coefficients. The vast majority of relationships formed such factors as the number of white blood cells, urine levels of diastase, amylase in blood, glucose levels that correlated with each other and with other parameters of the system. Among amylase and diastase on the first day of illness correlations were: $r=0,77$ in I group and $r=0,74$ in II. On the third day: $r=0,73$ and $r=0,68$ in I and II groups. It should be noted that parameters 
such as content of total protein, ALT, AST, hemoglobin, urea and creatinine in serum in the correlation matrix, likely did not form relationships with other indicators.

After analyzing the data, we found that in determining the level of procalcitonin, amylase, blood glucose, and urine diastase in comparison with other clinical parameters at admission, AP diagnosis was confirmed in $156(92,85 \%)$ and $54(87,09 \%)$ patients of I and II groups .

\section{Findings}

1. Diagnosis of acute pancreatitis should be based on results of deep clinical examination together with instrumental and laboratory tests.

2.AP diagnosis was confirmed in $156(92,85 \%)$ and $54(87,09 \%)$ patients of I and II groups at admission to hospital but it needs relevant examinations.

3. Due to the severity of AP results of some instrumental methods of diagnosis may be not informative and it need further clinical examination.

4.PCT certain level in the blood helps to make diagnosis of IPN and prevent complications by early surgical treatment, even in group of patients with severe and critical AP.

\section{References}

1.Ari Garber, Catherine Frakes, Zubin Arora, Prabhleen Chahal. Mechanisms and management of acute pancreatitis. Gastroenterology research and practice. 2018.

2.B.M. Gupta and K.K. Mueen Ahmed. "Pancreatitis Research in India: A Scientometric Assessment of Publications during 2007-16”. EC Gastroenterology and Digestive System 5.2 (2018): 37-47.

3.Fraiman Mark. “Common pancreatic disorders" (2015). 28 November, 2015. 2014-2017. https://liverandpancreassurgeon.com/ common-pancreatic-disorders/(Accessed on 28 December 2017)

4. D. Yadav and A. B. Lowenfels, "The epidemiology of pancreatitis and pancreatic cancer,” Gastroenterology, vol. 144, no. 6, pp. 1252-1261, 2013.

5. Kopchak V. M. Algoritm hirurgichnogo likuvannja gostrogo pankreatitu / V. M. Kopchak, I. V. Homjak, V. M. Shevchenko, O. V. Kit, A. I. Homjak // Klinichna hirurgija. - 2014. - \# 9.2. - S. 21-24. 6. Kopchak V. M , Gostrij nekrotichnij pankreatit: suchasni pidhodi do hirurgichnogo likuvannja/V.M. Kopchak, I. V. Homjak, K. V. Kopchak [i dr.] // Hark. hirurg. shkola. — 2008. — \# 2. — S. 109-111. 7.Kopchak V.M., Diferencijovane etapne hirurgichne likuvannja gostrogo nekrotichnogo pankreatitu/V.M. Kopchak, Homjak I.V// Vestnik kluba pankreatologov-avgust 2011,- s.42-45.

8. Nichitajlo M.Ju. Pankreonekroz. Profilaktika infikuvannja ta likuvannja infekcijnih uskladnen' / M.Ju. Nichitajlo, O.P. Kondratjuk, Ju.V. Snopok // Ukraïns'kij zhurnal hirurgiï. — 2009. — \# 4. — S. 104-108.

9.Propp., A.R. Klinicheskie paralleli/ kompjuternoj tomografii i intraopepacionnih kistoznih obrazovanij podzheludochnoj zhelezi/ A.R. Propp // Vestnik Hirurgii im. I.I. Grekova.-2011.- tom 170

10. Savel'ev B.C. Pankreonekrozy / B.C. Savel'ev, M.I. Filimonov, S.Z. Burnevich.// M.: OOO

"Medicinskoe informacionnoe agentstvo", 2008. - 264

11.Annals of Surgery.-2012.-Vol. 256. - P. 875-880).

12.Organ failure and infection of pancreatic necrosis as determinants of mortality in patients with acute pancreatitis/ M.S. Petrov, S.Shanbag, M. Chakraborty [ et al.]// Gastroenterology.-2010.- Vol.139.-P.813820.

13.Petrov M.S. Infected pancreatic necrosis: not necessarily a late event in acute pancreatitis/ M.S.

Petrov, V. Chong, J.A. Windsor// World J. Gastroenterol.-2011.-Vol.17.-P.3173-3176. 